\title{
High Summer Temperatures Have No Role in Breaking Physical Dormancy Among Seeds of Fireprone Cistaceae: A Reinterpretation of Luna (2020)
}

Byron B. Lamont ( $\sim$ B.Lamont@curtin.edu.au )

Curtin University https://orcid.org/0000-0001-9279-7149

Geoffrey E. Burrows

Charles Sturt University

Dylan Korczynskyj

The University of Notre Dame

\section{Research Article}

Keywords: Cistaceae, heat-released dormancy, germination, priming, summer temperatures

Posted Date: May 12th, 2021

DOI: https://doi.org/10.21203/rs.3.rs-498835/v1

License: (c) (i) This work is licensed under a Creative Commons Attribution 4.0 International License.

Read Full License 


\section{Abstract}

In a unique study, Luna (2020) examined the viability and germination of 12 hard-seeded Cistaceae in the Mediterranean Basin by alternating a prolonged summer-type-temperature $\left(50 / 20^{\circ} \mathrm{C}\right.$ at $12 \mathrm{~h}$ cycles) treatment with a fire-type heat pulse. A re-analysis of their data shows that the summer treatment applied before the heat pulse was superfluous as similar high levels of germination under ambient conditions were attained with the heat pulse only. The abundance of hard seeds remaining when the summer treatment was applied after the heat pulse is better explained by ungerminated seeds having become hard again rather than not responding, i.e., showing secondary physical dormancy, and thus became 'desensitized' to their environment. While this response is adaptive, such a retarding effect will be limited in practice as most fires are expected in autumn, at least historically, and are thus close to the start of optimal winter conditions for germination. Future studies should concentrate on the fate of the water-gap plug during such alternating treatments and also ensure that realistic summer temperature regimes are used.

\section{Introduction}

There has been recent interest in conditions that promote germination of 'hard' seeds (that do not imbibe water when soaked at ambient temperatures) with a focus on the family Cistaceae. Santana et al. (2020) concluded that climate and not fire-proneness was the key to understanding the evolution of Mediterranean species in this family, giving high summer temperatures as more significant than fire heat in stimulating germination. Much of the argument for a major role of high summer temperatures in promoting germination of the Cistaceae arises from experiments among other taxa that show application of temperatures above ambient but below those associated with fire, such as $50 / 20^{\circ} \mathrm{C}$ for one month, give levels of germination above the controls (Ooi et al. 2014, Cochrane 2017). Such temperatures can be reached (briefly) by soil surfaces over summer in mediterranean climates (Brits 1986, Moreira and Pausas 2012). However, Moreira and Pausas (2012) showed fire-type temperatures caused much greater germination of hard-seeded Cistaceae than summer-type temperatures. Here, the greater levels of response to the higher temperatures associated with fire are simply viewed as exaptations (Lamont and He 2017) by the climate advocates.

The possibility of a synergistic effect between high summer temperatures and fire on eight Cistus species and four Halimium species (Cistaceae) has recently been examined by Luna (2020). They exposed these species to $1-2$ months at $50^{\circ} \mathrm{C}$ continuously or $50 / 20^{\circ} \mathrm{C}$ at 12 -h cycles and compared the results against dry heat at $100^{\circ} \mathrm{C}$ for $10 \mathrm{~min}$. All pretreatments were followed by incubation at $20^{\circ} \mathrm{C}$. In addition, Luna alternated the 'summer' and heat pretreatments to see if this had any differential effect. They concluded that high summer temperatures primed ('sensitized') the seeds for maximum germination in the presence of fire such that they "work together" to break physical dormancy. Submission to a heat pulse before summer failed to do that - many seeds were shown to be hard after incubation. Cistaceae are able to imbibe water once the 'water gap' (chalazal oculus) opens in response to heat (Gama-Arachchige et al. 2013). We cross-referenced the data Luna (2020) provided and performed separate analyses with a view 
to seeking an alternative explanation - that fire heat was sufficient in itself to break dormancy and that any ungerminated seeds present had in fact became hard again over the month of postfire high temperatures (as shown possible for Trifolium subterraneum, Hagon and Ballard 1970). We further examined the likelihood that fires occur early rather than late in the fireprone season so providing little opportunity for postfire, high summer temperatures to reduce subsequent winter germination. We also comment on what can be considered realistic summer temperatures to apply to hard seeds in future studies.

\section{Methods}

Germination data for eight Cistus species and four Halimium species (Cistaceae) were selected from the Supporting Material in Luna (2020). They were subjected to one or two-way analyses of variance using Vassarstats.net (@Richard Lowry, 1998-2020). Soil temperature data were collated from Brits (1986). The literature was searched for data on a) where Cistaceae seeds are stored in space, b) likely temperatures reached by soil-stored seeds over the year, and c) monthly values of variables likely to affect the incidence of fire and conditions suitable for germination in the W Mediterranean Basin. These data were collated to identify the time of year when: a) the vegetation is most vulnerable to ignition, and b) conditions are optimal for germination.

\section{Results And Discussion}

Luna (2020) noted that most ungerminated seeds that had been given a heat treatment afterone month at $50 / 20^{\circ} \mathrm{C}$ were soft (they imbibed water when immersed) in contrast to those that were heated before the summer treatment. As a result, they suggested that summer temperatures prime ('sensitize') the seeds to soften more readily in the presence of fire-type heat and thus serve to promote germination. The grounds for the sensitizing effect by the summer pretreatment was the heat-then-summer treatment gave $32.6 \%$ germination and the summer-then-heat treatment $80.7 \%$ germination $(P<0.0001$, paired $t$-test, recalculated from Table S4 in Luna 2020). However, this pairwise comparison confounds two treatments given simultaneously: a summer treatment at time 1 and 2, and a heat treatment at time 2 and 1 that lacks controls. Other treatments (undertaken under the same conditions with the same batches of seeds but considered apart by Luna) included a control, summer treatment, heat treatment, and a summer-thenheat treatment (Table 1). Together, these show that germination was negligible in both the control and summer treatment, i.e., high summer temperatures did not promote germination. Fire-type heat caused a 7-8 times increase in germination, whether or not the seeds received a summer treatment. That is, the seeds did not need to be 'sensitized' to germinate fully in response to the heat pulse. A similar comparison can be made by replacing the heat-then-summer treatment by the summer-then-heat treatment (Table 2). Here, both sets of heated seeds germinated much more than the unheated $(72 \%$ of variance), but it is the interaction effect that is of most interest: the heat-then-summer sequence yielded $55 \%$ fewer germinated seeds than the summer-then-heat sequence. Luna (2020) interpreted this as failure of most of the heat-then-summer-treated seeds to be softened by the heat in contrast to the summer-then- 
heat-treated. But Table 1 makes it clear that summer priming was not required in the presence of the same heat treatment.

\section{Table 1}

2-way ANOVA of \pm summer treatment $\left(50 / 20^{\circ} \mathrm{C}\right.$ for $\left.1 \mathrm{mo}\right)$ and \pm heat treatment $\left(100^{\circ} \mathrm{C}\right.$ for 10 $\mathrm{min})$ that followed the summer treatment for mean germination \pm SD (\%) of 12 Cistaceae species at $20^{\circ} \mathrm{C}$. Calculated from Tables S3 and S4 in Luna ${ }^{1}$ (2020). Different superscript letters indicate significant differences at $P<0.01$ according to Tukey's HSD test.

\begin{tabular}{|llllll|}
\hline Germination & Control & Summer (time 1) & Source of variation & df & $\boldsymbol{P}$ \\
\hline No heat & $9.9 \pm 7.5^{\mathrm{b}}$ & $4.3 \pm 6.5^{\mathrm{b}}$ & \pm Summer & 1 & 0.7656 \\
\hline Heat (time 2) & $73.0 \pm 17.4^{\mathrm{a}}$ & $80.7 \pm 15.1^{\mathrm{a}}$ & \pm Heat & 1 & $<0.0001$ \\
& & & Interaction & 1 & 0.0732 \\
\hline & & Error & 44 & \\
\hline
\end{tabular}

Table 2

2-way ANOVA of \pm summer treatment $\left(50 / 20^{\circ} \mathrm{C}\right.$ for $\left.1 \mathrm{mo}\right)$ and \pm heat treatment $\left(100^{\circ} \mathrm{C}\right.$ for $\left.10 \mathrm{~min}\right)$ that preceded the summer treatment for mean germination $\pm \mathrm{SD}(\%)$ of 12 Cistaceae species at $20^{\circ} \mathrm{C}$.

Calculated from Tables S3 and S4 in Luna ${ }^{1}$ (2020). Different superscript letters indicate significant differences at $P<0.01$ according to Tukey's HSD test.

\begin{tabular}{|c|c|c|c|c|c|c|}
\hline Germination & Control & $\begin{array}{l}\text { Summer } \\
\text { (time 2) }\end{array}$ & $\begin{array}{l}\text { Source of } \\
\text { variation }\end{array}$ & df & $P$ & $\begin{array}{l}\text { Contribution to } \\
\text { variance (\%) }\end{array}$ \\
\hline No heat & $9.9 \pm 7.5^{c}$ & $4.3 \pm 6.5^{c}$ & \pm Heat & 1 & $<.0001$ & 71.5 \\
\hline \multirow[t]{3}{*}{$\begin{array}{l}\text { Heat (time } \\
\text { 1) }\end{array}$} & $\begin{array}{l}73.0 \pm \\
17.4^{\mathrm{a}}\end{array}$ & $32.6 \pm 27.7^{b}$ & \pm Summer & 1 & $<.0001$ & 18.1 \\
\hline & & & Interaction & 1 & 0.0001 & 10.4 \\
\hline & & & Error & 44 & & \\
\hline
\end{tabular}

A more likely explanation is that $40 \%$ of the presummer heated seeds had gone back into dormancy by becoming hard-seeded again as they dried out at $50 / 20^{\circ} \mathrm{C}$ over the ensuing month, a case of secondary physical dormancy. Micrographs and diagrams of the region in Cistaceae (Corral et al 1989, Nandi 1998, Gama-Arachchige et al. 2013) show that it is feasible for the retracted chalazal plug to be pushed back into the pore as the seed continues to desiccate. In support, Hagon and Ballard (1970) showed that scarified seeds of Trifolium subterraneum became hard again when stored at $5 \%$ humidity and $20^{\circ} \mathrm{C}$, not unlike summer drought conditions although at lower temperatures. They further noted that the strophiole resealed under these conditions, a point missed by those who consider secondary dormancy is not possible among hard-seeded species. Luna (2020) was aware of this reference but chose the 'sensitizing' view because they believed that secondary dormancy was not possible among seeds with physical dormancy, and felt it fitted better with their data (personal communication). However, it is difficult to see why seeds would need 'sensitizing' before responding to such an extreme treatment as dry heat at $100^{\circ} \mathrm{C}$ for $10 \mathrm{~min}$, and species used by Luna have produced as high levels of germination in the past, sometimes 
at lower temperatures for shorter exposure times, without the need for any priming (Thanos et al. 1992, Moreira et al. 2010, Luna et al. 2019).

Fluctuating dormancy has also been recorded among other Cistaceae: Fumana ericoides seeds were shown to go from soft to hard and soft again over time (Llorens et al. 2008). Most Cistus clusii seeds from two populations did not germinate after storing them air $d r y$ at $4^{\circ} \mathrm{C}$, in contrast to those kept at room temperature (Castro and Romero-García 1999). Most Helianthemum salicifolium seeds would no longer germinate after storing under "cold, $d r y$ " conditions in contrast to those kept at room temperature (Sánchez et al. 2014). We interpret both these cases as drying having imposed physical dormancy but note that Castro and Romero-García (1999) thought it was secondary physiological dormancy without checking the seeds for hardness nor appreciating that cold stratification requires moist conditions. Both these cases are consistent with the dry summer treatment of Luna (2020) 'desensitizing' some seeds by imposing dormancy on them (Table 2).

If low humidity is the key, then a month at low humidity might be as effective in restoring physical dormancy in Cistaceae as the $50 / 20^{\circ} \mathrm{C}$ used here. The heat-then-summer-treated seeds did remain viable according to Luna's 'cut' test and so these would be available to germinate following a subsequent fire. Thus, the response can be considered adaptive. This also can explain the few soft ungerminated seeds among those in the summer-then-heat-treated seeds: they had not yet had time to harden again. Assuming that the cut test is unreliable under these circumstances, it is also possible that the seeds which failed to germinate had actually died through the additional desiccation that would now occur if the pore remained unplugged over the extended period at $50^{\circ} \mathrm{C}$. [One of us, $\mathrm{GB}$, observed considerable additional water loss by Acacia seeds once the lens had popped though they did not die nor become hard again]. We agree with Luna that the relative location of the pore and plug needs to be examined by electron microscopy after various drying/heating treatments to resolve these alternative interpretations (personal communication).

Bastida and Talavera (2002) showed that most seeds of two Cistus species were stored beneath the plant crown. Tuberaria guttata seeds are stored $<10 \mathrm{~cm}$ from the parent plant (Guarino, Ferrario and Mossa 2005). Further, Cistaceae seeds are tiny ( $<2 \mathrm{mg}$ ) and spheroid (Bastida et al. 2009) so will easily penetrate the litter to reach the soil. These observations indicate that invariably Cistaceae seeds will be stored in litter-rich parts of the soil surface. Seeds of some species are dispersed by harvester ants but these are unlikely to account for more than $20 \%$ of their final location (Bastida et al. 2009). Some seeds can be ingested without harm by ruminants - here the seeds remain in the dung and are not exposed to sunlight (Ramos, Robles \& Castro 2006). Seeds of various Cistaceae stored beneath the plant crown to a depth of $50 \mathrm{~mm}$ averaged 1400-4000 $\mathrm{m}^{-2}$ (Herranz et al. 1999, Bastida and Talavera 2002). Dias et al. (2019) noted that the hypocotyl of $C$. ladanifer could extend to $22 \mathrm{~mm}$ and suggested this represented the maximum depth from which seeds could emerge unless surface soil was removed postfire (as may occur, Lamont et al. 1993). 
What temperatures then are reached at soil locations where Cistaceae seeds are likely to be stored? Brits (1986) studied the likely temperature fluctuations in pre- and post-burn surface soil in detail. For a site matching parts of the Mediterranean Basin, this work showed for the hottest month of the year that, at a soil depth of $5 \mathrm{~mm}$, the warmest 12 -h period of the day averaged $41^{\circ} \mathrm{C}$ and the coolest $22^{\circ} \mathrm{C}$ under light shade, and $28^{\circ} \mathrm{C}$ and $22^{\circ} \mathrm{C}$ under heavy shade (Table 3, see Moreira and Pausas 2012 for similar results). Thus, a summer pretreatment temperature at $50^{\circ} \mathrm{C}$ continuously for 1-2 months (Luna 2020) appears extremely high compared with expected summer temperatures at a depth of $5 \mathrm{~mm}$ even for mineral soil exposed after fire $\left(47 / 28^{\circ} \mathrm{C}\right.$, Table 3$)$, while that at $50 / 20^{\circ} \mathrm{C} 12$-h cycles seems a reasonable simulation of unburnt sites under light shade. However, the data reviewed above indicate that heavily shaded conditions at greater (cooler) depths are more likely for stored Cistaceae seeds in the Mediterranean Basin.

\section{Table 3}

Mean daily temperatures (to nearest $0.5^{\circ} \mathrm{C}$ ) at a depth of $5 \mathrm{~mm}$ for the warmest month of the year at the $3 / 4$ position (midway between the mean and maximum for the warmest $12 \mathrm{~h}$ ) and $1 / 4$ position (midway between mean and minimum for the coolest $12 \mathrm{~h}$ ) of the temperature range for three possible locations in shrubland. Compiled from Brits (1986) for a mild Mediterranean-type climate in South Africa. These provide a guide as to suitable temperatures to set on a 12/12-h cycle if attempting to simulate temperature conditions at the hottest time of year where stored seeds are located at $5 \mathrm{~mm}$ depth.

\begin{tabular}{|llll|}
\hline $\begin{array}{l}\text { Part of temperature } \\
\text { range }\end{array}$ & $\begin{array}{l}\text { Exposed gap } \\
\text { (postburn) }\end{array}$ & $\begin{array}{l}\text { Light shade } \\
\text { (unburnt) }\end{array}$ & $\begin{array}{l}\text { Heavy shade } \\
\text { (unburnt) }\end{array}$ \\
\hline 3/4 position & 46.5 & 41 & 27.5 \\
\hline $1 / 4$ position & 27.5 & 22 & 22.5 \\
\hline
\end{tabular}

The fire season in the Mediterranean Basin is considered to cover the period June (early summer) to September (early autumn) (Moriondo et al. 2006, Arca et al. 2012). This is supported by the abrupt but broad peak in fire 'danger' days at this time (Dimitrakopoulos et al. 2011) (Fig. 1). The moisture content of living fine foliage of Cistus species is used as an index of fire-proneness (Pellizzaro et al. 2007, Chuvieco et al. 2009) and low levels cover this period. Mean air temperatures also peak during the fire season. Monthly rainfall is at a minimum but does rise sharply in September, at least on the E side of the Iberian Peninsula (the source of Cistaceae studied by Luna 2020). As a suitable ignition source, the incidence of lightning shows that there is a sharp peak in September to December (Rivas Soriano and de Pablo 2002, Price and Federmesser 2006). At a depth of $5 \mathrm{~mm}$, means of the monthly soil temperatures at the extremes of postfire bare ground and prefire dense shade peak in July (Brits (1986). We note that the deep-shade pattern is almost the same as that for the Stevenson-screen air temperatures for Valencia (www.climatestotravel.com/climate/spain/valencia) and indicates this could be used as a reasonable surrogate for shaded surface soils.

Putting these data together shows that, when the fire regime is controlled by lightning, fires are most likely to occur at the end of the fireprone season, September (Fig. 1). This is about six weeks away (OctoberNovember) from soil conditions optimal for germination of Cistaceae seeds $\left(15-20^{\circ} \mathrm{C}\right.$, moist soil) (Herranz et al. 1999, Moreira et al. 2010, Dias et al. 2019, Luna et al. 2019, Luna 2020). Thus, the period between breaking dormancy and germination opportunity is short, soil temperatures are $7^{\circ} \mathrm{C}$ less than the 
summer peak, and autumn rains are already substantial. This means that any return to dormancy as suggested here during the remaining postfire, summer-autumn period will be short so that it has little role in reducing the extent to which previously heated seeds will germinate. More important will be the type of fire (He, Lamont and Pausas 2019) and properties of the wet season (Céspedes et al. 2012). We agree with Luna (personal communication) that seed burial under different field conditions is required to ensure future studies mimic what occurs in nature.

In conclusion, the simulated summer treatments need to be compatible with where seeds are actually stored over summer. It is clear that a continuous $50^{\circ} \mathrm{C}$ for $1-2$ months has no equivalent in nature and its only use might be in the context of exploring pre-adaptations (Lamont and He 2017). Most buried seeds will be well insulated from sunlight and mean temperatures in the order of $20-40^{\circ} \mathrm{C}$, as obtained under shade over the hottest summer month under a mediterranean climate by Brits (1986), appear more reasonable. Any differential effect of varying the sequence of heat and 'summer' treatments is of ecological and management relevance. If the interest is in the effect of long periods of severe summer heat following fire on seed viability and germination, then a fire-type heat treatment followed by 1-2 months at $50 / 20^{\circ} \mathrm{C}$ realistically simulates conditions that Brits (1986) determined for postfire bare areas at a depth of $5 \mathrm{~mm}$ (Table 3). It is well established that late season fires result in greater seedling establishment than early season fires (Enright and Lamont 1989). The usual explanation is in terms of greater dormancy-breaking efficiency (or seed release by serotinous species) by more intense fires rather than early fires resulting in a return to dormancy before winter rains begin as our preferred interpretation of Luna's data. Only studies that overtly studied the presence of dormancy cycling would be in a position to distinguish these two possibilities. The results could be added to guidelines on the most suitable time for management fires, bearing in mind that Enright and Lamont (1989) showed that recruitment success of early and late fires tended to merge with time.

\section{Declarations}

\section{Acknowledgements}

Thanks to Juli Pausas and Belén Luna for comments on the manuscript.

\section{Author contributions}

$\mathrm{BBL}$ conceived the project, collated the literature, undertook the analyses, prepared the tables and figure, liaised with Belén Luna and other colleagues, and wrote the manuscript, GEB assisted with testing ideas and editing the manuscript, DK located and documented the references and collated the germination data.

\section{Competing interests}

We declare no competing interests.

\section{Data archive}


All data analysed statistically given in Supporting Material to Luna (2020)

\section{References}

1. Arca B, Pellizzaro G, Duce P, Salis M, Bacciu V, Spano D, ... \& Scoccimarro E (2012) Potential changes in fire probability and severity under climate change scenarios in Mediterranean areas. In: Spano D, Bacciu V, Salis M and Sirca C. (eds) Modelling Fire Behaviour and Risk. Department of Science for Nature and Environmental Resources, University of Sassari, Euro-Mediterranean Center for Climate Changes, Sassari, Italy, pp 92-98

2. Bastida F, Talavera S (2002) Temporal and spatial patterns of seed dispersal in two Cistus species (Cistaceae). Ann Bot 89:427-434

3. Bastida F, Talavera S, Ortiz PL, Arista M (2009) The interaction between Cistaceae and a highly specific seed-harvester ant in a Mediterranean scrubland. Plant Biol 11:46-56

4. Castro J, Romero-García AT (1999) Dormancy and germination in Cistus clusii (Cistaceae): effect of biotic and abiotic factors. Rev. Ecol. (Terre Vie) 54, 19-28 (1999)

5. Céspedes B, Torres I, Urbieta IR, Moreno JM (2012) Effects of changes in the timing and duration of the wet season on the germination of the soil seed bank of a seeder-dominated Mediterranean shrubland. Plant Ecol 213:919-931

6. Chuvieco E, González I, Verdú F, Aguado I, Yebra M (2009) Prediction of fire occurrence from live fuel moisture content measurements in a Mediterranean ecosystem. Internat J Wildl Fire 18:430-441

7. Cochane A (2017) Are we underestimating the impact of rising summer temperatures on dormancy loss in hard-seeded species? Aust J Bot 65:248-256

8. Corral R, Pérez-García F, Pita JM (1989) Seed morphology and histology in four species of Cistus L. (Cistaceae). Phytomorphology 39:75-80

9. Dias SL, Pereira PI, Dias SA (2019) Seed germination in Cistus ladanifer. heat shock, physical dormancy, soil temperatures and significance to natural regeneration. Plants 8:63

10. Dimitrakopoulos AP, Bemmerzouk AM, Mitsopoulos ID (2011) Evaluation of the Canadian fire weather index system in an eastern Mediterranean environment. Meteorol Appl 18:83-93

11. Enright NJ, Lamont BB (1989) Seed banks, fire season, safe sites and seedling recruitment in five cooccurring Banksia species. J Ecol 77:1111-1122

12. Gama-Arachchige NS, Baskin JM, Geneve RL, Baskin CC (2013) Identification and characterization of ten new water gaps in seeds and fruits with physical dormancy and classification of water-gap complexes. Ann Bot 112:69-84

13. Guarino R, Ferrario B, Mossa L (2005) A stochastic model of seed dispersal pattern to assess seed predation by ants in annual dry grasslands. Plant Ecol 178:225-235

14. Hagon MW, Ballard LAT (1970) Reversibility of strophiolar permeability to water in seeds of subterranean clover (Trifolium subterraneum L). Aust J Biol Sci 23:519-528

15. He T, Lamont BB, Pausas JG (2019) Fire as a key driver of Earth's biodiversity. Biol Rev 94:983-2010 
16. Lamont BB, He T (2017) Fire-proneness as a prerequisite for the evolution of fire-adapted traits. Trends Plant Sci 22:278-288

17. Lamont BB, Witkowski ETF, Enright NJ (1993) Post-fire litter microsites: safe for seeds, unsafe for seedlings. Ecology 74:501-512

18. Llorens L, Pons M, Gil L, Boira H (2008) Seasonality of seed production and germination trends of Fumana ericoides (Cistaceae) in the west semiarid Mediterranean region. J Arid Environ 72:121-126

19. Luna B (2020) Fire and summer temperatures work together breaking physical seed dormancy. Sci Rep 10:1-10

20. Luna B, Chamorro D, Pérez B (2019) Effect of heat on seed germination and viability in species of Cistaceae. Plant Ecol Divers 12:151-158

21. Moreira B, Pausas JG (2012) Tanned or burned: The role of fire in shaping physical seed dormancy. PLoS ONE 7(12):e51523

22. Moreira B, Tormo J, Estrelles E, Pausas JG (2010) Disentangling the role of heat and smoke as germination cues in Mediterranean Basin flora. Ann Bot 105:627-635

23. Moriondo M, Good P, Durao R, Bindi M, Giannakopoulos C, Corte-Real J (2006) Potential impact of climate change on fire risk in the Mediterranean area. Climate Res 31:85-95

24. Nandi OI (1998) Ovule and seed anatomy of Cistaceae and related Malvanae. Plant Syst Evol 209:239-264

25. Ooi MKJ, Denham AJ, Santana VM, V.M. \& Auld TD (2014) Temperature thresholds of physically dormant seeds and plant functional response to fire: variation among species and relative impact of climate change. Ecol Evol 4:656-671

26. Pellizzaro G, Cesaraccio C, Duce P, Ventura A, Zara P (2007) Relationships between seasonal patterns of live fuel moisture and meteorological drought indices for Mediterranean shrubland species. Internat J Wildl Fire 16:232-241

27. Price C, Federmesser B (2006) Lightning-rainfall relationships in Mediterranean winter thunderstorms. Geophys Res Letters 33:L07813

28. Ramos ME, Robles AB, Castro J (2006) Efficiency of endozoochorous seed dispersal in six dry-fruited species (Cistaceae): from seed ingestion to early seedling establishment. Plant Ecol 185:97-106

29. Rivas Soriano L, de Pablo F (2002) Maritime cloud-to-ground lightning: The western Mediterranean Sea. J Geophys Res: Atmospheres 107(D21):ACL-A15

30. Sánchez AM, Luzuriaga AL, Peralta AL, Escudero A (2014) Environmental control of germination in semi-arid Mediterranean systems: the case of annuals on gypsum soils. Seed science research, 24(3), 247.16. Herranz, J.M., Ferrandis, P. \& Martínez-Sánchez, J.J. Influence of heat on seed germination of nine woody Cistaceae species. Internat. J. Wildl. Fire 9, 173-182 (1999)

31. Santana VM, Alday JG, Adamo I, Alloza JA, Jaime BM Climate, and not fire, drives the phylogenetic clustering of species with hard-coated seeds in Mediterranean Basin communities. Perspect. Plant Ecol., Evol. Syst. 125545 (2020) 
32. Thanos CA, Georgidou K, Kadis C, Pantazi C (1992) Cistaceae: a plant family with hard seeds. Israel J Bot 41:251-263

\section{Figures}

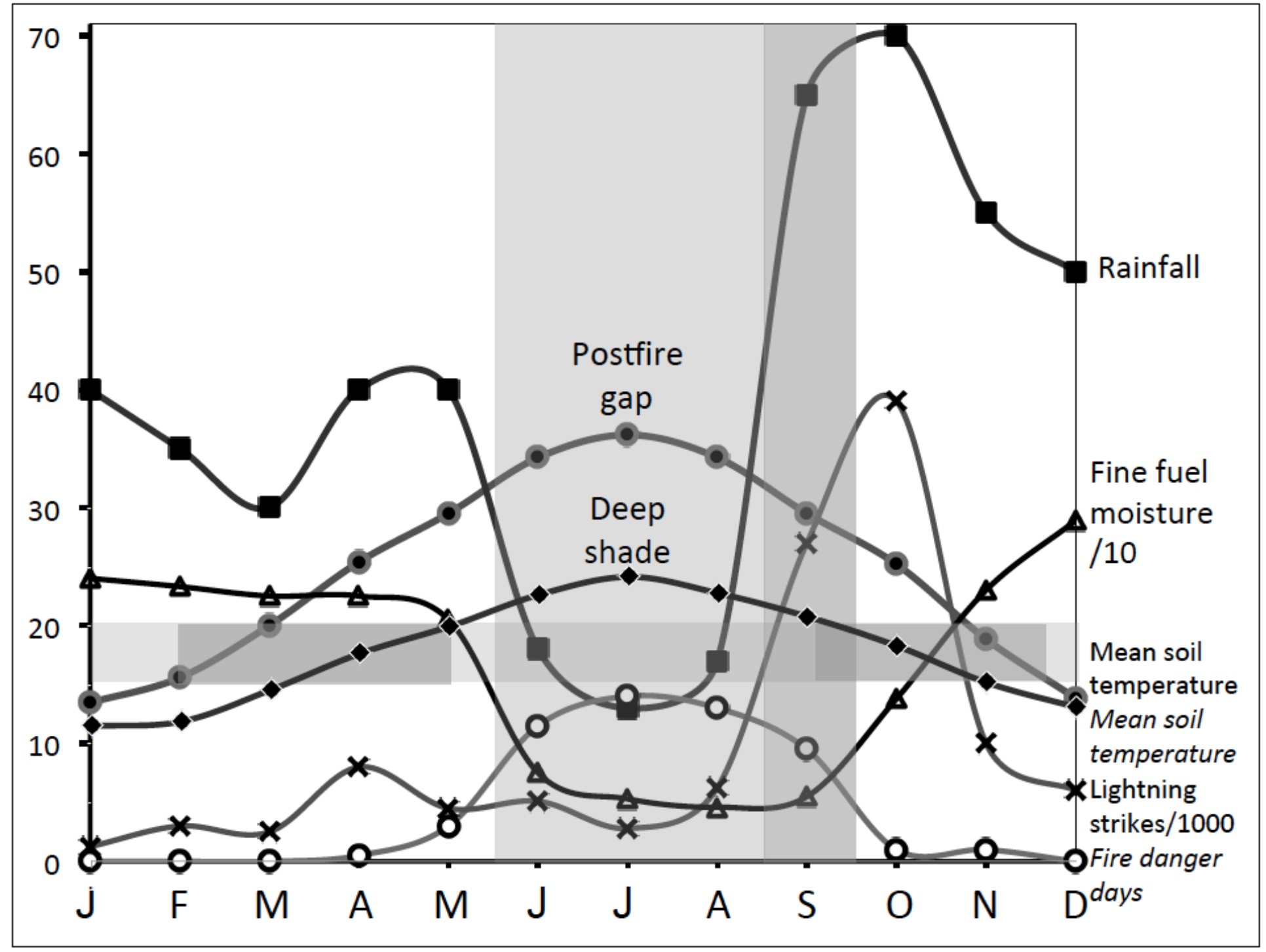

Figure 1

Monthly means (initials of month beginning from January given) for variables related to breaking dormancy and promoting germination of Cistaceae species in the Mediterranean Basin. Rainfall $(\mathrm{mm})$ for Valencia on the E edge of the Iberian Peninsula (from www.climatestotravel.com/climate/spain/valencia), moisture content (\% dry weight) of living fine foliage of Cistus monspeliensis as an (inverse) index of fire-proneness (from Pellizzaro et al. 2007), soil temperature $\left({ }^{\circ} \mathrm{C}\right)$ in postfire gaps or under deep shade at a depth of $5 \mathrm{~mm}$ in an equivalent mediterraneaen climate (Cape, S Africa), with months reversed to coincide with seasons of the Northern Hemisphere, lightning strikes in the Mediterranean Sea at the E edge of the Iberian Peninsula (from Rivas Soriano and de Pablo 2002) and number of high fire danger days in Crete based on the Canadian fire 
weather index (from Dimitrakopoulos et al.19 2011). Vertical grey area corresponds to the accepted fire season in the Mediterranean Basin (from Moriondo et al. 2006, Arca et al. 2012) with the darker grey monthly period to the right appearing to be most vulnerable to ignition based on these variables in the absence of human interference. Means of the monthly soil temperatures at the extremes of postfire bare ground and prefire dense shade are added (collated from Brits 1986). Horizontal grey area represents the incubation temperatures used to germinate all 12 Cistaceae species studied by Luna (2020) following optimal heat pretreatments that resulted in 74-97\% germination (Thanos et al. 1992, Herranz et al. 1999, Dias et al. 2019, Moreira et al. 2010, Luna et al. 2019, Luna 2020). The darker areas within this area correspond to the times of year where soil temperatures are within this optimum range. 